Aksiologiya: Jurnal Pengabdian Kepada Masyarakat

Vol.5, No. 2, Mei 2021 Hal 154 - 162

ISSN 2528-4967 (print) dan ISSN 2548-219X (online)

\title{
Pemanfaatan Multimedia Dalam Pengembangan dan Promosi Potensi Desa Wisata Adiluhur Kebumen
}

\author{
Ade Wahyudin ${ }^{1}$, David Kristiadi ${ }^{2}$, Ardian Setio Utomo ${ }^{3}$, Arum Marwati ${ }^{4}$, \\ Riska Ana Gulang 5 \\ 1,2Program Studi Manajemen Teknik Studio Produksi, \\ Sekolah Tinggi Multi Media Yogyakarta \\ ${ }^{3,4}$ Program Studi Manajemen Informasi Komunikasi, \\ Sekolah Tinggi Multi Media Yogyakarta \\ ${ }^{5}$ Program Studi Teknologi Permainan, Sekolah Tinggi Multi Media Yogyakarta \\ Email : adew001@kominfo.go.id', davi004@kominfo.go.id², ardi008@kominfo. \\ go.id ${ }^{3}$, arum002@kominfo.go.id ${ }^{4}$,risk002@kominfo.go.id ${ }^{5}$
}

\begin{abstract}
ABSTRAK
Perkembangan teknologi komputer telah merubah gaya hidup masyarakat, dimana masyarakat semakin dimudahkan dalam mendapatkan informasi dan melaksanakan aktifitasnya dengan berbagai aplikasi dan gadget. Hal ini menjadi peluang dalam pengelolaan desa wisata, sehingga pengelola desa wisata mampu secara interaktif terhubung dengan wisatawan dengan memanfaatkan media sosial. Desa Wisata Adiluhur Kebumen merupakan salah satu desa yang memiliki potensi objek wisata yang bisa dikembangkan dan dipromosikan melalui multimedia. Taman Reptil Adiluhur dan Kampung Wisata Inggris Kebumen merupakan potensi objek wisata yang menjanjikan dari Desa Wisata Adiluhur, namun pengelolaannya masih belum optimal. Oleh karena itu tujuan dari pengabdian masyarakat ini adalah untuk meningkatkan kemampuan warga untuk mempromosikan potensi desa wisata. Metode yang digunakan adalah penyuluhan dan pelatihan multi media kepada warga desa selain itu melakukan observasi, wawancara dan dokumentasi yang dilakukan kepada perwakilan pemerintah desa dan tokoh masyarakat. Kemudian disusun suatu strategi pengembangan dan promosi desa wisata menggunakan multimedia dan sosial media. Strategi tersebut antara lain pengotimalan website desa wisata dengan menggunakan search engine optimizer dan pemanfaatan platform media sosia yang tepat. Hasil dari pengabdian masyarakat ini, peserta mampu memproduksi karya multi media yang dapat digunakan sebagai sarana promosi Desa Wisata Adiluhur.
\end{abstract}

Kata Kunci : desa wisata; media sosial; multimedia; promosi.

\section{Utilization of Multimedia in the Development and Promotion of the Potential of the Adiluhur Kebumen Tourism Village}

\begin{abstract}
The development of computer technology has changed people's lifestyles, where people are easy to getting the information and carrying out its activities by many applications and gadgets. This is an opportunity in the management of a tourist village so that the tourism village manager can interactively connect with tourists by utilizing social media. Adiluhur Kebumen Tourism Village is one of the villages that have potential tourism objects that can be developed and promoted through multimedia. Adiluhur Reptile Park and Kebumen English Tourism Village are promising tourism potentials of the Adiluhur Tourism Village, but the management is still not optimal. Therefore the purpose of community service is to increase the ability of citizens to promote the potential of tourism villages. The method used is multi-media outreach and training to villagers in addition to conducting


observations, interviews, and documentation conducted to village government representatives and community leaders. Then developed a strategy for developing and promoting rural tourism using multimedia and social media. These strategies include optimizing the tourism village website by using a search engine optimizer and using an appropriate social media platform. As a result of this community service, participants were able to produce multi-media works that could be used as a means of promoting Adiluhur Tourism Village.

Keywords: multimedia; promotion; social media; tourism village

\section{PENDAHULUAN}

Multimedia menjadi istilah yang umum bagi masyarakat dewasa ini, terutama bila dilihat dari perkembangan teknologi komputer dan internet yang menyebabkan akses terhadap multimedia semakin mudah. sehingga memiliki peranan yang penting dalam kehidupan kita di masyarakatdewasaini(Surjono,2017). Perkembangan teknologi multimedia pada perangkat laptop, smartphone, TV dan elektronik lainnya membuka potensi besar dalam perubahan cara belajar, cara memperoleh informasi, cara berbisnis dan sebagainya (Arifin et al., 2015).

Dengan perkembangan multimedia membuka peluang bagi masyarakat untuk mempermudah aktivitas mereka sehari-hari seperti berkomunikasi dengan orang lain, berinteraksi, bekerja atau bahkan untuk media hiburan. Salah satu pemanfaatan multimedia sebagai media promosi pada sektor pariwisata terutama wilayah pedesaaan (Atiko et al., 2016). Karena pariwisata memiliki potensi ekonomi yang cukup besar dan mampu mendorong perekonomian wilayah pedesaan dan terpencil. Multimedia mampu memperkenalkan berbagai potensi desa yang belum dikenal atau tergali kepada masyarakat luas. Sehingga berpeluang mendorong sektor lainnya seperti pertanian, perkebunan, dan UMKM. Hal ini untuk menciptakan suatu konsep desa wisata yang berintergrasi dengan perkembangan teknologi dan multimedia (Pawestri, 2014) (Pambudi et al., 2018).

Desa wisata merupakan suatu wilayah pedesaan yang menawarkan keaslian baik dari segi sosial budaya, adat-istiadat, keseharian, arsitektur tradisional, struktur tata ruang desa yang disajikan dalam suatu suatu bentuk integrasi komponen pariwisata antara lain seperti atraksi, akomodasi dan fasilitas pendukung (Syafi'i \& Suwandono,2015).Untukmembangun desa wisata diperlukan beberapa komponen yang mendukung antara lain (Zakaria \& Suprihardjo, 2014): (1) Memiliki potensi pariwisata, seni, dan budaya khas daerah setempat; (2) Lokasi desa masuk dalam lingkup daerah pengembangan pariwisata atau setidaknya berada dalam koridor dan rutepaketperjalananwisata yang sudah dijual; (3) Diutamakan telah tersedia tenaga pengelola, pelatih, dan pelakupelaku pariwisata, seni dan budaya; (4) Aksesibilitas dan infrastruktur mendukung program Desa Wisata; (5) Terjaminnya keamanan, ketertiban, dan kebersihan.

Desa Adiluhur, kecamatan Adimulyo, Kabupaten kebumen 
merupakan salah satu contoh desa yang sesuai untuk menerapkan konsep tersebut. Hal ini karena Desa Wisata Adiluhur memiliki latar belakang prestasi antara lain, memperoleh Juara 1 Festival Desa Wisata 2019 yang diselenggarakan oleh Disporawisata Kabupaten Kebumen di bulan April 2019 (Desa Wisata Adiluhur Kebumen Raih Juara 1 Gelar Desa Wisata 2019 Tingkat Jateng - Tribun Jateng, 2019). Kemudian, juara 1 desa wisata terbaik tingkat Provinsi Jawa Tengah 2019 yang digelar Tanggal 20-21 Juli 2019 di Lapangan Garnisun, Kota Semarang diikuti oleh 31 perwakilan dari seluruh kota/kabupaten di Jawa Tengah (DESA WISATA ADILUHUR, JUARA 1 DESA WISATA TERBAIK TINGKAT PROVINSI JAWA TENGAH 2019 Dinas Kepemudaan dan Olahraga dan Pariwisata Kabupaten Kebumen, 2019). Namun, potensi yang dimiliki desa ini hanya dikenal secara lokal, belum secara nasional sehingga perlu dikembangkan lagi potensi yang ada dengan memanfaatkan multi media.

Ada beberapa potensi wisata yang dimiliki Desa Wisata Adiluhur antara lain Taman Reptil Desa Wisata Adiluhur (TARA), Kampung Wisata Inggris Kebumen (KWIK), Museum Pertanian Kuno, Padepokan Karate BKC, Argowisata dan Homestay (Desa Wisata Adiluhur - Adimulyo, n.d.). Namun, promosi dan sosialisasi yang kurang optimal menyebabkan kurangnya informasi masyarakat luas mengenai Desa Wisata Adiluhur. Hal ini bisa dilihat dengan sebagian besar pengunjung desa wisata berasal dari wilayah kebumen dan sekitarnya.
Selain itu, lokasi desa yang cukup jauh dari kota, kualitas akses jalan menuju desa yang kurang baik. Walaupun demikian pemerintah dan masyarakat desa, berusaha secara gotong royong untuk memperbaiki permasalahan tersebut. Karena diharapkan konsep Desa Wisata Adiluhur mampu memberikan peningkatan kualitas hidup masyarakat desa, dimana pada umumnya penduduk desa masih menggantungkan hidupnya pada sektor pertanian.

Atasdasarlatarbelakangdiatas, maka kegiatan pengabdian masyarakat dilaksanakan dengan mengambil topik Pelatihan dan Penyuluhan Bijak Menggunakan Multimedia Dalam Rangka Pemberdayaan Masyarakat di Desa Wisata Adiluhur Kabupaten Kebumen, Jawa Tengah. Dimana salah satu output dari kegiatan pengabdian kepada masyarakat tersebut adalah perlu adanya kajian strategi pengembangan potensi dan promosi Desa Wisata Adiluhur dengan memanfaatkan perkembangan teknologi dibidang multimedia. Multimedia tidak hanya digunakan sebagai alat untuk memperkenalkan desa kepada masyarakat luas namun mengembangkan berbagai macam potensi pariwisata yang ada pada Desa Wisata Adiluhur.

\section{METODE PELAKSANAAN}

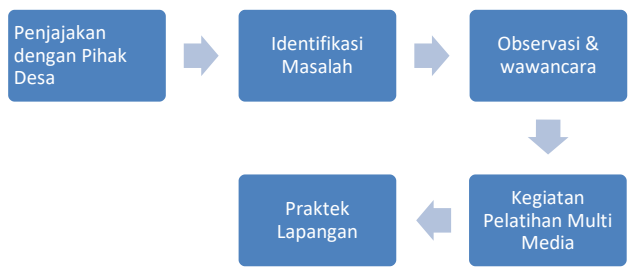

Gambar 1: Flowchart Pelaksanaan PKM 
Pada flowchart yang diilustrasikan pada Gambar 1, pelaksanaan Pengabdian masyarakat di Desa Wisata Adiluhur, dimulai dari penjajakan dengan pihak pemangku kepentingan di Desa Wisata Adiluhur. Hal ini dilakukan untuk mengidentifikasi masalah dan kebutuhan terhadap kegiatan pengabdian masyarakat dengan menggunakan metode observasi dan wawancara. Informasi didapatkan dari berbagai pihak seperti warga masyarakat desa, pengelola tempat wisata hingga Kepala Desa Adiluhur.

Kemudian, setelah mendapatkan informasi dan data yang dibutuhkan, maka disusunlah kegiatan pengabdian masyarakat dengan mengambil tema pelatihan multimedia dalam rangka pemberdayaan masyarakat di Desa Wisata Adiluhur. Pelatihan multimedia terbagi menjadi lima materi yaitu pengenalan multimedia untuk pengembangan dan promosi desa wisata, pelatihan produksi konten audio video, penyuluhan e-commerce dalam promosi desa wisata, penyuluhan penggunaan media sosial secara, dan penyuluhan penggunaan Youtube.

Pelaksanaan Pengabdian kepada masyarakat diselenggarakan pada tanggal 28 - 29 Oktober 2019 dalam bentuk kegiatan diskusi, penyuluhan dan pelatihan berkenaan dengan penggunaan multimedia untuk pemberdayaan masyarakat desa. Peserta berasal dari organisasi kepemudaan desa dan pengelola objek wisata di Desa Adiluhur. Pelaksanaannya bertempat di Balai
Desa Adiluhur, Museum Pertanian dan Ruang Pertemuan Taman Reptil.

Bagian terakhir adalah bagaimana peserta pengabdian masyarakat mengimplementasikan dan memprakatekan materi yang dipelajari selama kegiatan. Sehingga akan diharapkan peserta mampu memberikan kontribusi bagi kemajuan desa dengan mengimplementasikan materi yang telah didapatkan. Adapun praktek yang dilakukan adalah praktek audio visual dari proses penggalian ide, produksi, editting hingga upload di Youtube. Selanjutnya, strategi pemanfaatan multimedia dalam pengembangan dam promosi potensi Desa Wisata Adiluhur disusun dengan pendekatan deskriptif kualitatif.

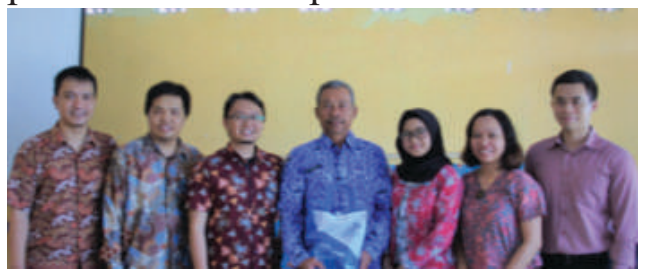

Gambar 2: Tim PkM STMM dan

Kepala Desa Adiluhur

\section{HASIL DAN PEMBAHASAN Pelaksanaan Pengabdian Kepada Masyarakat}

Pelaksanaan

kegiatan ini bertujuan untuk memberikan pemahaman dan masukan mengenai pemanfaatan multimedia untuk pemberdayaan masyarakat desa. Kegiatan ini berlangsung dia hari dengan diikuti oleh 30 peserta. Adapun hasil dari pelaksanaan pengabdian kepada masyarkat dijabarkan sebagai berikut:

1. Pengenalan Multimedia untuk Pengembangan dan Promosi Desa Wisata 
Penyuluhan ini dilaksanakan di Balai Desa Adiluhur pada hari pertama pelaksanaan, tanggal 28 Oktober 2019. Penyajiannya menitikberatkan kepada pengenalan multimedia, bagaimana perkembangan teknologi multimedia dapat merubah perilaku manusia dan bagaimana pemanfaatan multimedia dalam pengembangan dan promosi desa wisata secara optimal. Penyaji menyampaikan beberapa masukan, terutama mengenai penggunaan dan pemanfaatan konten multimedia pada website dan aplikasi media sosial sebagai sarana promosi dan pengembangan potensi desa wisata.

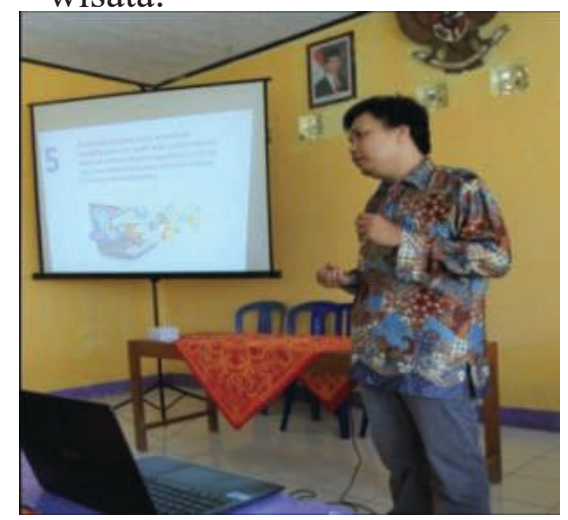

Gambar 3: Pemaparan Multimedia untuk Pengembangan dan Promosi Desa Wisata

1. Pelatihan Produksi Konten Audio Video

Penyuluhan ini dilaksanakan di Balai Desa Adiluhur dan Museum Pertanian pada hari pertama dan kedua pelaksanaan, tanggal 28 dan 29 Oktober 2019. Peserta dilatih untuk dapat menciptakan konten audio video secara sederhana menggunakan kamera yang ada pada smartphone. Pelatihan ini dimaksudkan peserta dapat membuat konten audio video untuk mempromosikan berbagai potensi desa wisata.

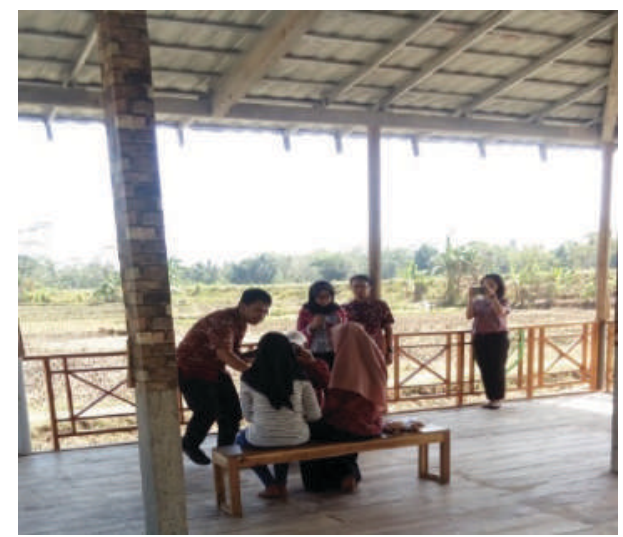

Gambar 4: Pelatihan Pembuatan Produksi Audio Video

Materi yang diberikan berupa teori videografi, teknik penggalian ide, teknik pengambilan gambar hingga editing video dengan menggunakanaplikasikinemaster. Peserta juga dituntut untuk dapat menghasilkan suatu karya video pada akhir pelatihan.

Hasil karya video peserta di upload Youtube. Salah satu karya peserta berjudul "Batik Alu Kebumen" dapat disaksikan pada link https://www.youtube.com/ watch?v=aHWB6Dft4Og

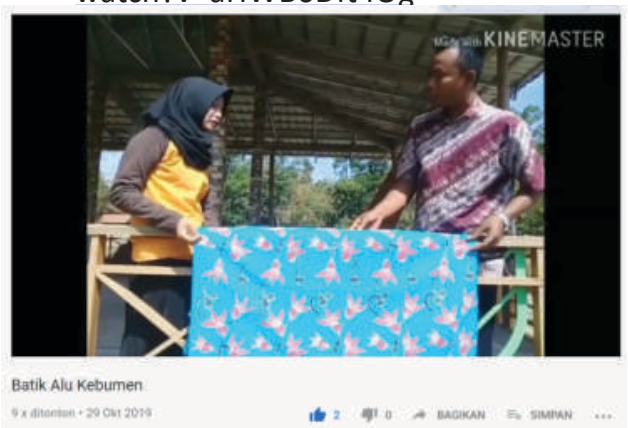

Gambar 5: Cuplikan video karya peserta PKM

2. Penyuluhan e-commerce dalam promosi Desa Wisata

Penyuluhan ini dilaksanakan di Ruang Pertemuan Taman Reptil pada hari kedua pelaksanaan, tanggal 29 Oktober 2019. Pemateri memberikan masukan bagaimana strategi promosi desa wisata dengan memanfaatkan aplikasi e-commerce dan sosial media secara efektif. Materi yang disajikan meliputi, bagaimanan 
menetapkan target pasar, bentuk konten yang disajikan, pemilihan platform aplikasi dan strategi pemasaran media sosial yang tepat.

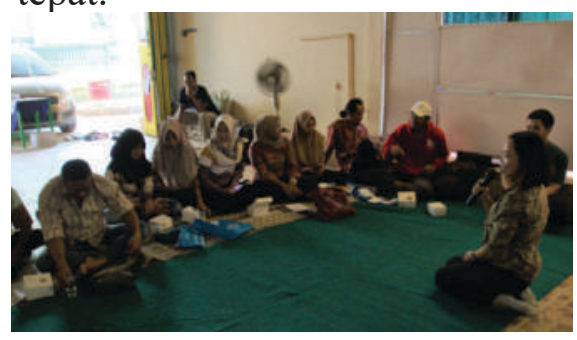

Gambar 6: Penyuluhan e-commerce

2. Penyuluhan Penggunaan Media Sosial Secara Bijak

Penyuluhan ini dilaksanakan di Ruang Pertemuan Taman Reptil pada hari kedua pelaksanaan, tanggal 29 Oktober 2019. Pada kegiatan pengabdian masyarakat ini, tidak hanya berusaha menggali potensi desa wisata, namun juga berusaha mengedukasi peserta untuk dapat menggunakan media sosial secara bijak. Hal ini dirasa penting, karena penggunaan media sosial sangat rentan terhadap penyalahgunaan dan mudahnya masyarakat terprovokasi berita bohong (hoax). Oleh karena itu, penyaji memberikan edukasi bagaimana menggunakan sosial media secara benar dan bagaimana menyaring berita sehingga tidak terpapar berita bohong, dimana pemaparan dilaksanakan secara interaktif dengan didukung berbagai studi kasus, fakta dan informasi.

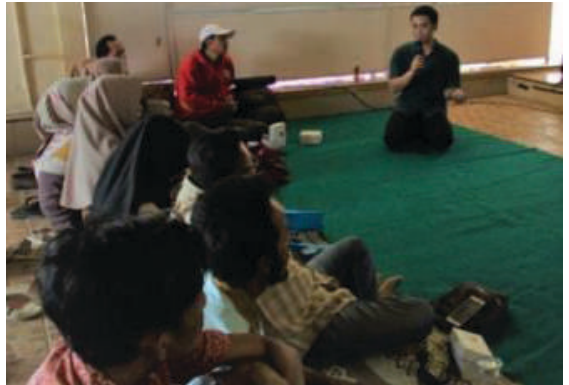

Gambar 7: Penyuluhan

Penggunaan Media Sosial Secara

Bijak

3. Penyuluhan Penggunaan Youtube Penyuluhan ini dilaksanakan di Ruang Pertemuan Taman Reptil pada hari kedua pelaksanaan, tanggal 29 Oktober 2019. Pada bagian terakhir, merupakan kelanjutan dari materi pelatihan produksi konten audio video. Dimana peserta diajarkan penggunaan aplikasi Youtube dan bagaimana penggunaan Youtube tersebut untuk pengembangan dan promosi desa wisata. Peserta diajarkan bagaimana penggali ide dalam pembuatan konten video, strategi pemasaran menggunakan Youtube.

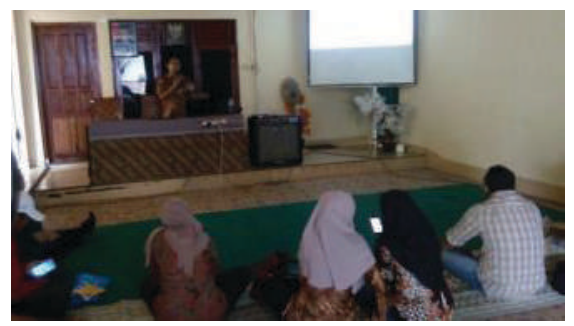

Gambar 8: Penyuluhan Penggunaan Youtube

\section{Strategi Pengembangan dan Promosi Desa Wisata}

Secara keseluruhan Desa Wisata Adiluhur memiliki potensi dan peluang yang sangat besar dalam meningkatkan sektor pariwisata di 
Kabupaten Kebumen dan mendorong peningkatan perekonomian masyarakat lokal. Dari banyak objek wisata yang ada di Desa Wisata Adiluhur, Taman Reptil Adiluhur (TARA) dan Kampung Wisata Inggris Kebumen (KWIK) dapat menjadi andalan dalam meningkatkan Brand Awareness Desa Wisata. Kedua objek wisata tersebut mampu mendatangkan pengunjung yang cukup banyak, terutama TARA yang menjadi atraksi lokal yang cukup populer bagi warga Kebumen.

Penggunaan teknologi dan multimedia dalam pengembangan dan promosi akan menjadi bagian yang sangat penting untuk meningkatkan brand awareness Desa Wisata Adiluhur. Sehingga akan merubah pola pengelolaan dan konsep bisnis desa wisata. Strategi pemanfaatan multimedia dan media sosial untuk meningkatkan brand awareness dalam pengelolaan desa wisata yang efektif dan tepat menjadi kunci keberhasilan (Moriansyah, 2015). Strategi peningkatan brand awareness tersebut antara lain:

1. Penggunaan SEO (Search Engine Optimizer) pada website Desa Wisata Adiluhur.

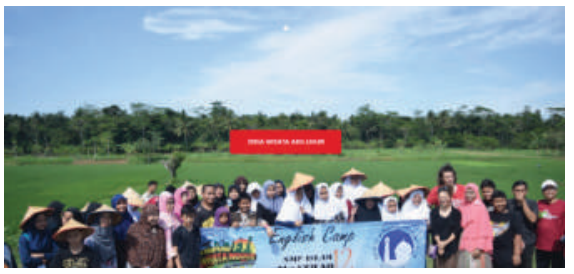

Gambar 9: Tampilan homepage website Desa Wisata Adiluhur

Desa Wisata Adiluhur memiliki website yaitu https:// desawisataadiluhur.com/. Pada website tersebut menampikan dan menawarkan berbagai atraksi, objek wisata, akomodasi dan fasilitas beserta dengan harga paket wisata yang cukup terjangkau oleh masyarakat.

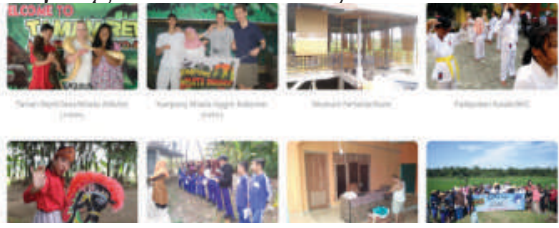

Gambar 10: Potensi Desa

Wisata yang ditampilkan pada website

Sehingga perlu adanya optimasi website di mesin pencarian yang optimal dengan menggunakan SEO.SEOberupayamengoptimasi website untuk mendapatkan peringkat teratas di hasil pencarian. Dengan mendapatkan ranking tinggi di hasil pencarian, potensi trafik dan kunjungan ke website pun meningkat.

2. Penggunaan Media Sosial Untuk Promosi Desa Wisata.

Pengelola objek wisata yang ada di Desa Wisata Adiluhur telah memiliki akun media sosial seperti Facebook dan Instagram. Sebagai contoh Kampung Wisata Inggris Kebumen (KWIK) memiliki akun Facebook (https://www.facebook.com/ kwik.kebumen) dan Instagram (https://www.instagram.com/ ampungwisatainggriskebumen/). Selain itu, objek wisata Taman ReptilAdiluhurjugamemilikiakun Facebook (https://www.facebook. com/TamanReptilAdiluhur) dan Instagram (https:// 
w w w. ins tag ram.com / tamanreptiladiluhur/).

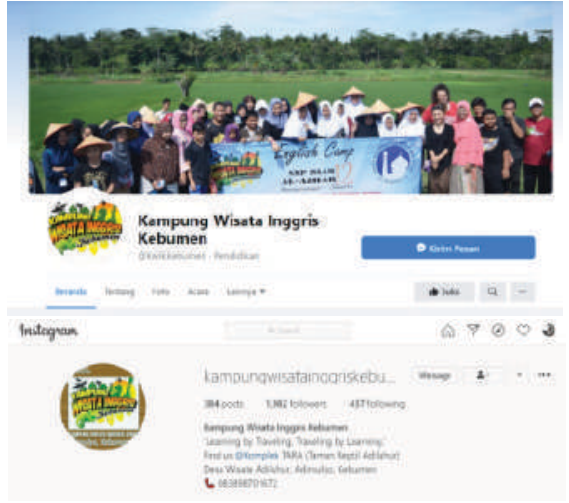

Gambar 11: Instagram dan Facebook Kampung Wisata Inggris Kebumen

Penggunaan media sosial menjadi bagian penting dalam promosi potensi Desa Wisata Adiluhur. Pengelola objek wisata selalu aktif memberikan informasi dan memposting kegiatan yang dilaksanakan di objek wisata tersebut. Sehingga diharapkan mampumenarikminatpengunjung lebih banyak lagi dari berbagai daerah, tidak hanya dalam skala lokal namun nasional.

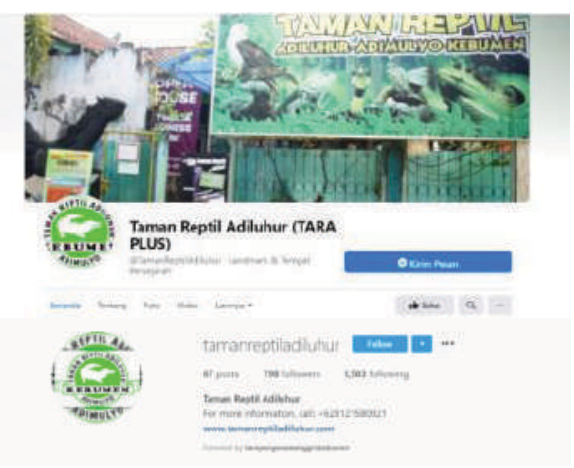

Gambar 12: Instagram dan facebook Taman Reptil Adiluhur

\section{SIMPULAN}

Berdasarkan pembahasan maka dapat disimpulkan, antara lain:
1. Desa Wisata Adiluhur memiliki banyak potensi wisata yang menjanjikan dan menarik wisatawan, sehinggamampuuntuk menjadi salah satu penggerak perekonomian masyarakat desa.

2. Pelaksanaan pengabdian masyarakat melakukan penyuluhan dan pelatihan berkaitan dengan pemanfaatan multimedia dalam pengembangan dan promosi Desa Wisata Adiluhur. Sehingga masyarakat desa memiliki pengetahuan dalam pembuatankontendanpenyusunan strategi dalam pengelolaan desa wisata yang terintegrasi dengan perkembangan teknologi.

3. Perlunya penyusunan strategi yang komperhensif dalam pengmbangan dan promosi Desa Wisata Adiluhur dalam memanfaatkanmultimedia, seperti pemanfaatan SEO pada website desa wisata serta penggunaan multimedia dan social media sebagai media promosi.

\section{DAFTAR PUSTAKA}

Arifin, Y., Ricky, M. Y., \& Yesmaya, V. (2015). DIGITAL MULTIMEDIA (Ed.)). Bina Nusantara.

(Ariyanto Atiko, G., Hasanah Sudrajat, R., \& Nasionalita, K. (2016). ANALISIS STRATEGI PROMOSI PARIWISATA MELALUI MEDIA SOSIAL OLEH KEMENTRIAN PARIWISATA RI (studi deskriptif pada akun Instagram@indtravel).Jurnal Sosioteknologi, 15(3), 378389. https://doi.org/10.5614/ sostek.2016.15.3.6 
DESA WISATA ADILUHUR, JUARA

1 DESA WISATA TERBAIK

TINGKAT PROVINSI JAWA

TENGAH 2019 - Dinas

Kepemudaan dan Olahraga

dan Pariwisata Kabupaten

Kebumen. (2019). http://

www.pariwisatakebumen. com/2019/07/desa-wisataadiluhur-juara-1-desa.html

Desa Wisata Adiluhur - Adimulyo. (n.d.). Retrieved June 11, 2020, from https://desawisataadiluhur. com/

Desa Wisata Adiluhur Kebumen Raih Juara 1 Gelar Desa Wisata 2019 Tingkat Jateng - Tribun Jateng. (2019). https://jateng. tribunnews.com/2019/07/22/ desa-wisata-adiluhur-kebumenraih-juara-1-gelar-desa-wisata2019-tingkat-jateng

Moriansyah, L. (2015). Pemasaran Melalui Media Sosial: Antecedents Dan Consequences. Jurnal Penelitian Komunikasi Dan Opini Publik, 19(3), 187-196. https://doi.org/ http://dx.doi.org/10.33299/ jpkop.19.3.346

Pambudi, S. H., Sunarto, N., \& Setyono, P. (2018). Strategi Pengembangan Agrowisata dalam Mendukung Pembangunan Pertanian Studi Kasus di Desa Wisata Kaligono (Dewi Kano) Kecamatan Kaligesing Kabupaten Purworejo. Analisis Kebijakan Pertanian, 16(2), 165. https://doi.org/10.21082/ akp.v16n2.2018.165-184

Pawestri, I. A. (2014). TWITTER SEBAGAI MEDIA PROMOSI WISATA KOTA SEMARANG. AN-NIDA, 6(2), 101-110.

Pokdarwis KWIK Adimulyo Juara 2 Tingkat Provinsi Jawa Tengah - Dinas Kepemudaan dan Olahraga dan Pariwisata Kabupaten
Kebumen. (2018). http:// www.pariwisatakebumen. com/2018/07/pokdarwis-kwikadimulyo-juara-2-tingkat.html

Surjono, H. D. (2017). Multimedia Pembelajaran Interaktif: Konsep dan Pengembangan. In UNY Press (first, Issue Oktober). UNY Press. http://dstats.net/ download/http://blog.uny.ac.id/ hermansurjono/files/2018/02/ Multimedia-Pembelajaran2017-Cetak-smSC.pdf

Syafi'i, M., \& Suwandono, D. (2015). Perencanaan Desa Wisata Dengan Pendekatan Konsep Community Based Tourism (CBT) Di Desa Bedono, Kecamatan Sayung, Kabupaten Demak. Ruang, 1(2), 51-60. https://doi.org/10.14710/ ruang.1.2.61-70

Zakaria, F., \& Suprihardjo, D. (2014). Konsep Pengembangan Kawasan Desa Wisata di Desa Bandungan Kecamatan Pakong Kabupaten Pamekasan. Teknik Pomits, 3(2), C245-C249. https://doi.org/2337-3520 